\title{
Stability as a Key Factor for Bone Repair in Nonunion of Mandibular Osteotomy
}

\author{
Estabilidad como Factor Clave en la Reparación de la Nonunión de la Osteotomía Mandibular
}

Priscila Alves dos Santos ${ }^{1}$; Alexandre Elias Trivelato² ${ }^{2}$ Sergio Olate ${ }^{3}$; Luciana Asprino \& Márcio de Moraes ${ }^{1}$

DOS SANTOS, P. A.; TRIVELATO, A. E.; OLATE, S.; ASPRINO, L. \& DE MORAES, M. Stability as a key factor for bone repair in nonunion of mandibular osteotomy. Int. J. Morphol., 38(2):309-315, 2020.

SUMMARY: Stability is necessary to ensuring proper bone repair after osteotomies and fractures. The aim of this research was to analyze how the repair of pseudoarthrosis sites was affected by different conditions in related to soft tissue. An experimental study was designed with 18 New Zealand rabbits. Six study groups were formed. An osteotomy was performed on the mandibular body of each animal and muscle was installed at the osteotomy site to model pseudoarthrosis. Fixation by surgery was then carried out, using plates and screws. The animals were submitted to euthanasia after 21, 42 and 63 days to make a descriptive comparison of the histological results. No animal was lost during the experiment. In all the samples, bone formation was observed with different degrees of progress. Defects treated with or without removal of the tissue involved in pseudoarthrosis presented comparable bone repair, showing that stability of the bone segments allows the repair of adjacent tissue. In some samples cartilaginous tissue was associated with greater bone formation. Stabilization of the fracture is the key in bone repair; repair occurs whether or not the pseudoarthrosis tissue is removed.

KEY WORDS: Nonunion; Bone repair; Mandibular fracture; Mandibular osteotomy.

\section{INTRODUCTION}

Mandible fracture is close to $25 \%$ of maxillofacial fractures (Gassner et al., 2003). The etiology and clinical presentation is related to certain variables, such as the force of the trauma, the point to which it was applied, local conditions such as tooth presence, the patient's systemic conditions and the use of some drugs (Madsen et al., 2009; Tucker et al., 2013).

Andreassen et al. (1998) analyzed bone repair in subjects treated with rigid internal fixation (RIF) or under maxillomandibular block (MMB), finding that faster bone repair was observed in subjects with RIF, although after two months, both presented the same bone repair quality. Dodson et al. (1990) found no differences in complications when they compared patients with RIF and BMM. A logical conclusion from these two studies is that stability of the bone segments allows bone repair irrespective of where the stabilization is applied; bone repair is also observed in subjects treated with an external splint on the mandible (Tucker et al.).
Thus rigid or stable internal fixation using plates and screws has been a big pillar in the repair of maxillofacial fractures and osteotomies. Including the many advantages that it presents, its ability to stabilize segments with precise anatomical positioning help the bone repair in different clinical scenarios.

A complication in bone repair of osteotomies or fractures is the nonunion. Although the incidence is low, when it occurs it is difficult to treat and frequently requires further surgery. Lamphier et al. (2003) presented $4.8 \%$ of cases with nonunion, while Olate et al. (2013) presented only a single case in their sequence of 66 patients treated for fractures in the mandibular body. Seemann et al. (2010) also presented $4.8 \%$ cases with pseudoarthrosis; they determined that age, gender (including hormonal elements), presence of multiple fractures or the use of MMB had no correlation with the presence of pseudoarthrosis. This suggests that other local variables, or systemic variables specific to the patient, may be related with the occurrence of nonunion, one of which

\footnotetext{
${ }^{1}$ Department of Oral Diagnosis, Piracicaba Dental School, State University of Campinas, Brazil.

${ }^{2}$ Department of Oral and Maxillofacial Surgery and Periodontology, Riberao Preto Dental School, Sao Paulo University, Brazil.

${ }^{3}$ Centre of Excellence in Morphological and Surgical Studies \& Division of Oral, Facial and Maxillofacial Surgery, Universidad de La Frontera, Chile.
} 
is tobacco (Chen et al., 2018). In an economic analysis, Lee et al. (2019) indicated that nonunion was more frequent in the mandibular body of elderly subjects, and that these cases involved higher treatment costs and use of hospital resources than other types of mandibular fractures.

Failure of segment stability (Madsen et al.) and the presence of large spaces between the stabilized fragments (Olate et al. 2019) are associated with absence of bone repair and with the presence of inflammatory infiltrate or connective tissue, and such cases develop into nonunion. The aim of this research was to analyze bone repair in a pseudoarthrosis model generated in rabbit mandibles, determining the importance of stabilization of the fragments in bone repair.

\section{MATERIAL AND METHOD}

Eighteen New Zealand rabbits aged between 3 and 6 months were selected and separated into 6 groups of 3 animals each. The animals were kept with water and food ad libitum, and their daily functioning was cared for.

Fracture and pseudoarthrosis model. Mandibular fracture was realized by surgery with submandibular approach following the protocols of Thomsen \& Ericson (1987) and Alister at al. (2017). The approach allowed a vertical osteotomy $3 \mathrm{~mm}$ wide in the mandibular body, using a low-velocity drill.

The method for inducing pseudoarthrosis consisted in interposing muscle tissue into the osteotomy space (platysma muscle) for 21 days after the osteotomy, following observations described by Haug \& Schwimmer (1994) (Fig. 1).

For RIF was used a 1.5 straight plate and 4 screws (Fig. 2). The subjects were assigned to 6 groups with methodologies for the osteotomy, pseudoarthrosis model and euthanasia as presented below (Fig. 3).

Group 1. Osteotomy, immediate reduction and RIF; euthanasia at 21 days.

Group 2. Osteotomy and induction of pseudoarthrosis; 21 days a new surgical approach was created and the site fixed with plates and screws and without any kind of curettage; euthanasia at 42 days.

Group 3. Osteotomy and induction of pseudoarthrosis; at 21 days a new surgical approach was created, with extensive curettage of the pseudoarthrosis zone, followed by fixation with plates and screws; euthanasia at 42 days.
Group 4. Osteotomy, immediate reduction and RIF; euthanasia at 42 days.

Group 5. Osteotomy and induction of pseudoarthrosis; at 21 days a new surgical approach was created and the site fixed with plates and screws and without any kind of curettage; euthanasia at 63 days.

Group 6. Osteotomy and induction of pseudoarthrosis; at 21 days a new surgical approach was created, with extensive curettage of the pseudoarthrosis zone, followed by fixation with plates and screws; euthanasia at 63 days.

Histological analysis. After the experimental times of 21, 42 and 63 days after the first surgery, the animals were submitted to euthanasia. The surgical pieces were obtained by total resection and fixed in a solution of formalin $4 \%$. They were decalcified and routine histological processing was carried out; $6 \mathrm{~mm}$ slices were cut, with hematoxylineosin staining. Descriptive analysis was performed and comparison between groups was realized.

\section{RESULTS}

The experimental animals were kept without complications during the study period; no animal was lost. The following analyses were carried out for each group:

Group 1. Connective tissue and abundant chondrocytes were observed, with absence of granulation tissue and accompanied by osteogenic activity with immature bone tissue; tissue with organized structure and incipient bone repair (Fig. 4).

Group 2. Cartilaginous tissue was observed at the periphery of the defect, with osteogenic activity showing the presence of islands of immature bone tissue and discrete formation of bone callus; in all areas the presence of blood vessels and centres of ossification was observed (Fig. 5).

Group 3. Close to the osteosynthesis plate, remnants of cartilaginous tissue were observed in the absence of granulation tissue; advanced osteogenic activity was observed with presence of mainly mature bone tissue in the analysis zone. The presence of well structured bone callus was observed in the majority of the sample (Fig. 5).

Group 4. The presence of cartilage was observed, with absence of connective tissue and absence of granulation tissue. Well organized bone tissue was observed with presence of bone callus, blood vessels and centres of ossification in the majority of the samples (Fig. 4). 

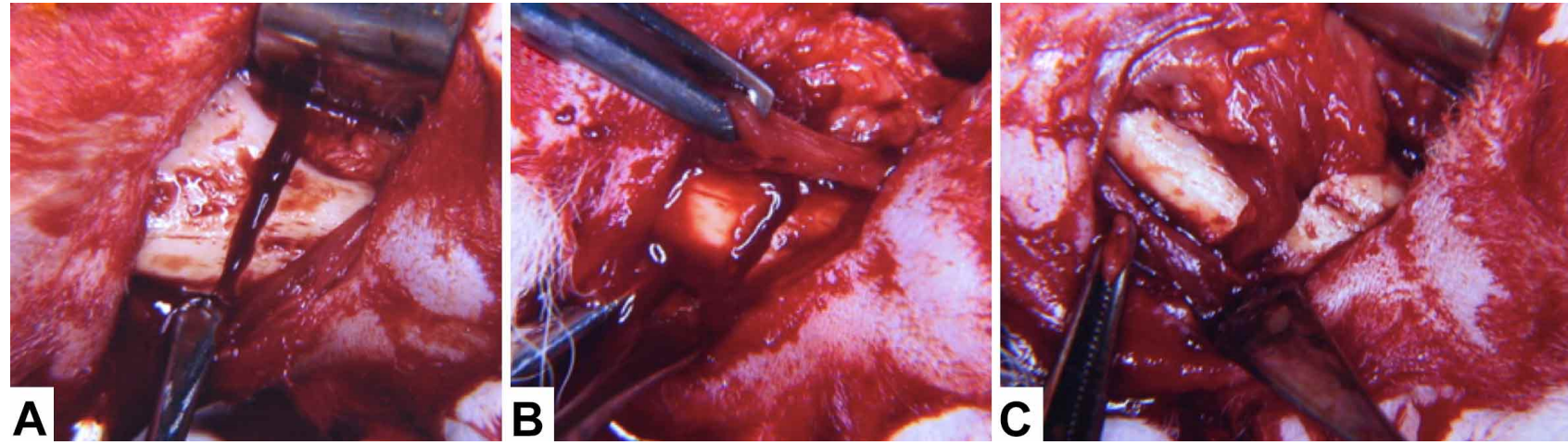

Fig. 1. Surgical model used in this investigation. A) Approach and osteotomy of the mandible; B) rotated flap of peripheral muscle ready to be installed on the osteotomy site; C) muscle installed to model pseudoarthrosis.
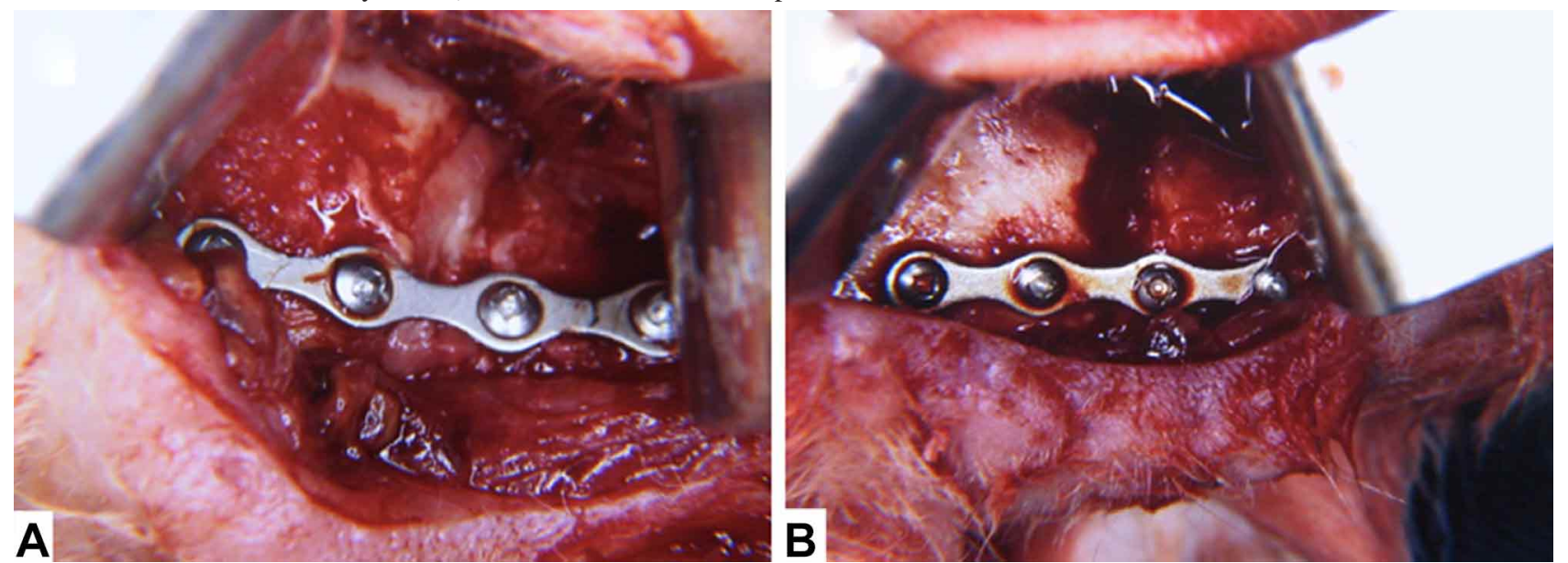

Fig. 2. Rigid internal fixation installed in the animals. A) group in which all the pseudoarthrosis tissue between the two bone segments was removed; B) group in which the tissue between the bone segments was left in place. In both groups, stabilization with plates and screws ensured the immobility of the segments.
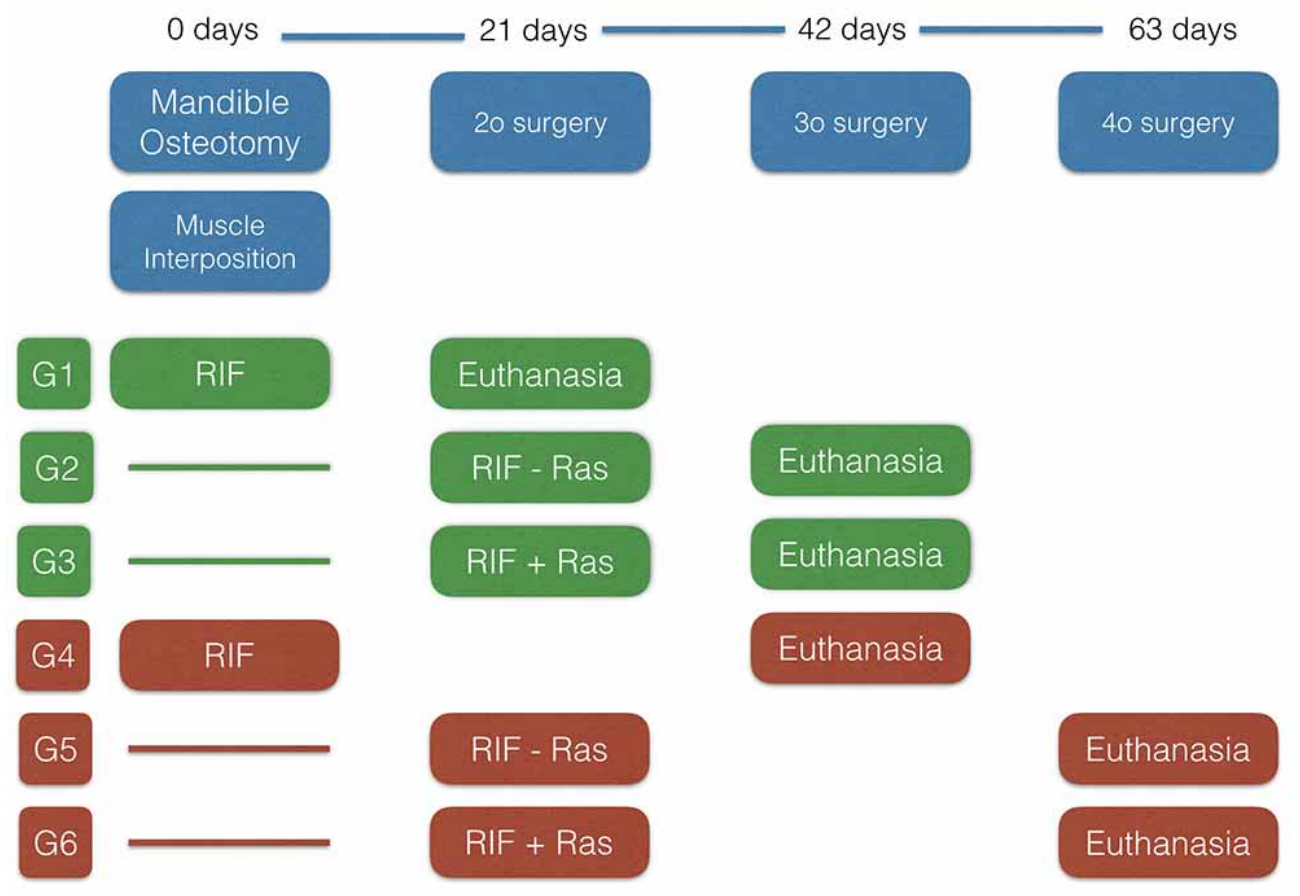

Fig. 3. Diagram of the experimental model used in this investigation. Analysis was carried out in both groups in accordance with this protocol. 

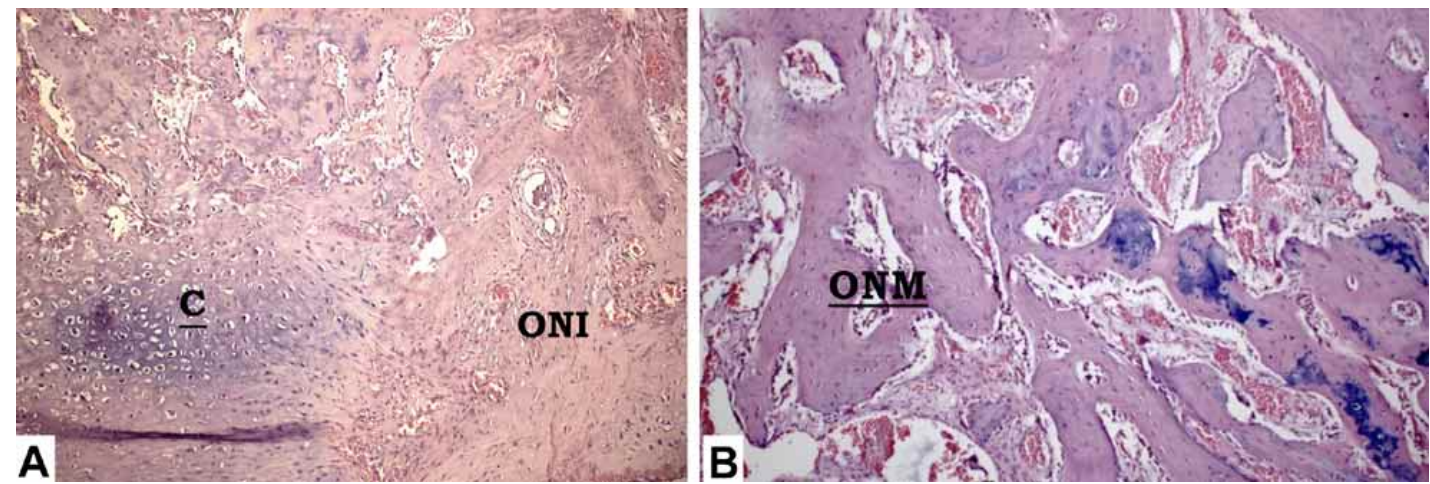

Fig. 4. Histological images in H-E (250mm) obtained from group 1 (A) and group 4 (B), treated with RIF immediately after the osteotomy and euthanasia after 21 days (A) and 42 days (B). (C): presence of homogeneous cartilaginous tissue; ONI: presence of immature new bone tissue; ONM: presence of mature new bone tissue.

Group 5. The presence of cartilage was observed at the periphery of the osteotomy, with presence of fibrous tissue; in one sample, presence of adipose tissue was observed; mature bone tissue was not observed in any of the samples, and tissue was maintained with some areas of connective tissue and areas of ossification, with presence of blood vessels indicative of structure in the ossification process (Fig. 6).
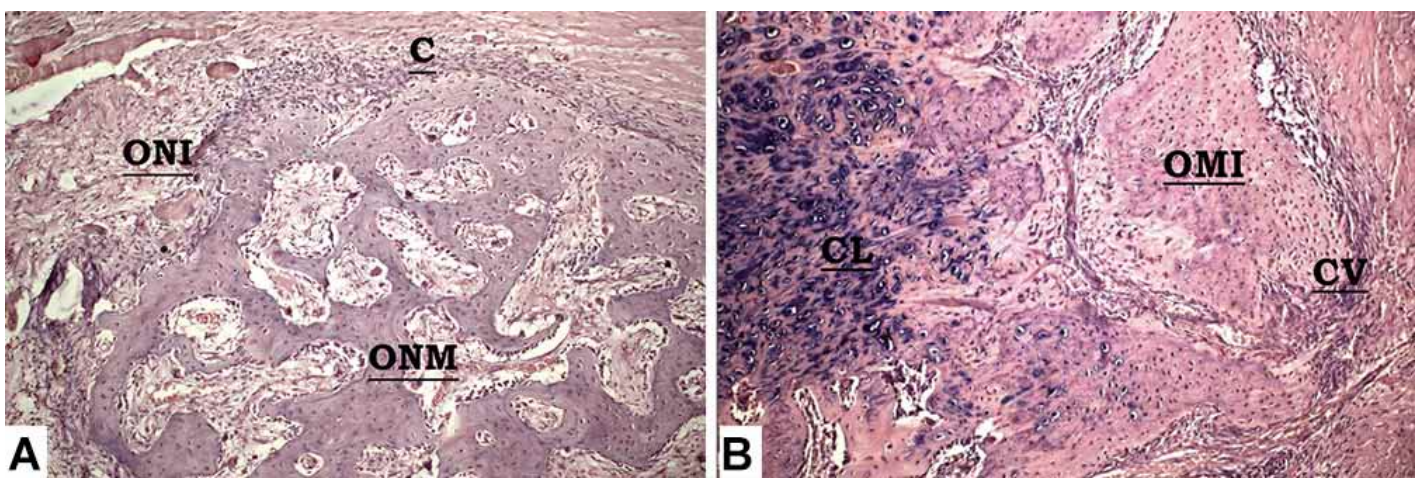

Fig. 5. Histological images in H-E $(250 \mathrm{~mm})$ obtained from group 2 (A) and group 5 (B), treated with RIF 21 days after provoking the pseudoarthrosis model and without removal of any type of tissue at the time of the second surgery to install the fixation. Euthanasia after 42 days (A) and 63 days (B). (C): presence of homogeneous cartilaginous tissue; ONI: presence of immature new bone tissue; ONM: presence of mature new bone tissue.
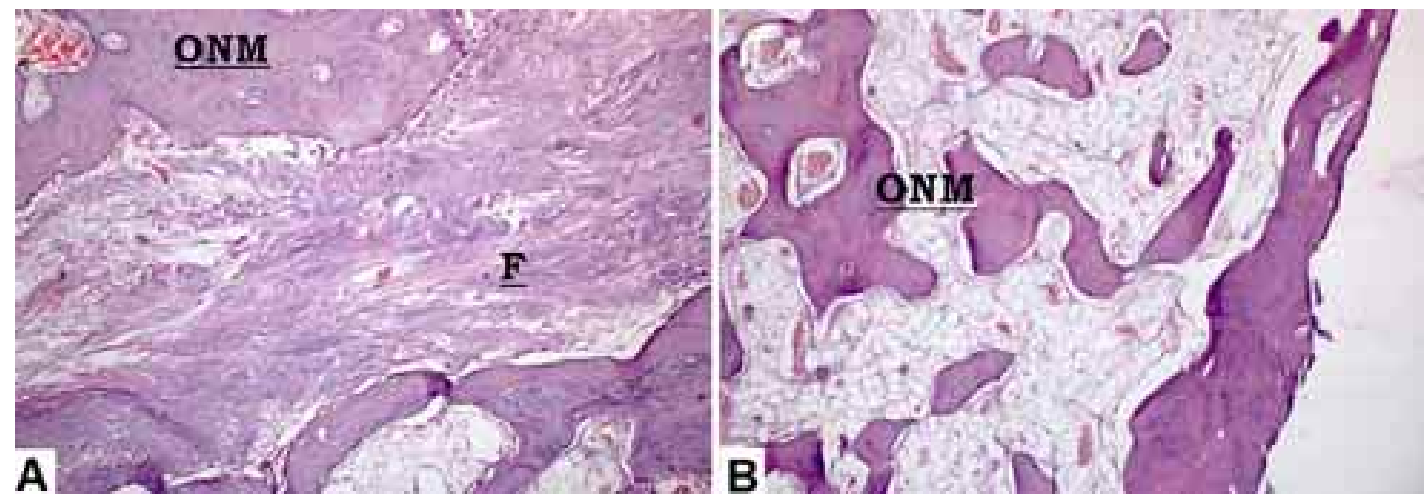

Fig. 6. Histological images in H-E (250mm) obtained from group 3 (A) and group 6 (B), treated with RIF 21 days after provoking the pseudoarthrosis model and with removal of all the tissue between the bone fragments at the time of the second surgery to install the fixation. Euthanasia after 42 days (A) and 63 days (B). (C): presence of cartilaginous tissue in the lateral regions of the defect; ONI: presence of immature new bone tissue; ONM: presence of mature new bone tissue. 


\section{DISCUSSION}

This work presents the results of bone repair in cases of pseudoarthrosis model in rabbits. The investigation was carried out smoothly and no animal was lost during the study.

When a fracture is treated in conditions of optimum stability using anatomical reduction and interfragmentary compression, bone repair occurs by primary or direct ossification, without formation of a periosteal callus (Delgado-Martínez \& Alcántara-Martos, 2006). However, when the fracture or osteotomy is not completely stabilized and space or mobility exists between the fragments, secondary or indirect ossification occurs, which is the commonest form of repair (Gerstenfeld et al., 2006). If the mobility exceeds the tolerance to deformation of the tissue present in the callus, alterations in the consolidation will occur such as pseudoarthrosis or hypertrophic nonunion (Green et al., 2005).

The speed of consolidation is influenced by the type of bone, the type of fracture, the method of treatment, and the patient's age and general state (Panteli et al., 2015; Ricketts et al., 2016). Local factors such as separation of the bone ends may also have an impact; this may be related with bone loss or resorption at the fracture site, interposition of soft tissues between the bone ends, excessive traction or the use of internal fixation (Wraighte \& Scammell, 2007; Jahagirdar \& Scammell, 2009).

In the facial skeleton, the repair of fractures and osteotomies generally occurs by endochondral ossification, based on the formation of bone callus from the periosteum and the endosteum. The process includes an inflammatory initial phase, cartilage formation, mineralisation and bone remodeling (Marsell \& Einhorn, 2011). Insufficient or interrupted immobilization and excessive separation of the bone fragments could produce pseudoarthrosis (Macki et al., 2016) and maintain a condition in which the bone segments function as a joint and not a solid mineralized structure.

The results of the recent study published by Olate $e t$ al. (2019) show the importance of the position and condition of the bone segments when the repair process of a fracture or osteotomy is in the initial stage. The distance between the bone ends established in the different groups defined the type of repair and the evolution of the repair process. When the separation between the mandible segments did not exceed $5 \mathrm{~mm}$, a clear endochondral repair was observed, while the group with a separation of $8 \mathrm{~mm}$ between the bone fragments presented consolidation of the fracture; the cicatrize consisted principally of fibrous tissue with abundant fibroblasts and no osteoblast integration. Bone repair in defects of the facial skeleton is influenced by the distance between the bone segments, their stability (immobilization) and environmental conditions (infection, quality of the periosteum, etc.) (Spanjer et al., 2017).

Thus the repair zone between the bone segments is highly active, since the cells present in nonunion areas are viable and versatile development. In an in vitro study, Boyan et al. (1992) reported that cells present in this structure are capable of responding to bone morphogenetic protein in the same way as mesenchymal cells. Iwakura et al. (2009) showed that the hypertrophic tissue present in the nonunion serves as a reservoir of cells with the potential to develop into chondrocytes or osteoblasts. The conclusions of these two works are related with our conclusions and suggest that the nonunion can develop into a bone repair site without the need for this tissue to be removed.

Wu \& Chen (1997) compared open and closed techniques for treating cases of nonunion. They reported that the closed technique produced faster bone repair, suggesting that a new operation of the nonunion site might damage vascular support, making repair slower. Muller et al. (2007) also reported that bone repair can occur when a new osteosynthesis system is installed without any need to treat (remove) the hypertrophic tissue at the nonunion site.

The versatility of the tissue involved in bone repair at osteotomy sites allows distraction osteogenesis to be developed over a long provisional period. Likewise contraction osteogenesis was confirmed by the study of Alkan et al. (2011), who reduced the mandible size in an animal model, achieving reduction and nonunion at the end of the mechanical procedure; the histological images showed that 3 months after movement was stopped, normal bone formation was obtained.

All these conditions indicate that the nonunion tissue between bone fragments presents a great potential; for this reason it is currently the focus of new treatment methods to improve the predictability of bone union in cases of complex pathologies or sequelae, and radiotherapy (Donneys et al., 2015). The application of low intensity pulsed ultrasound has also been investigated as a strategy in the fracture zone, increasing the differentiation of cells derived from the bone callus (Imai et al. 2014).

These results show that the stability and proximity of the bone fragments play great importance in proper bone repair. Factors like a long waiting time before stabilization of the fracture, use of tobacco and tooth extractions have 
been cited as risk factors for complications in fracture healing, including nonunion (Hsieh et al., 2019). For these reasons, the quality and quantity of the fixation material are critical through their ability to support the immobilization of the segments and provide sufficient mechanical stability for the patient and the type of fracture beingtreated (Rodriguez Chessa et al., 2014; de Medeiros et al., 2016; Meram et al., 2018).

\section{CONCLUSION}

It is concluded that this model to induce pseudoarthrosis was appropriate; the use of RIF allowed bone repair to occur even in groups in which pseudoarthrosis was provoked before the installation of RIF, and also in groups in which curettage of the zone was not carried out and the tissue between the fragments was left unaltered. Studies with a larger number of animals are necessary to review different protocols in the animal model and improve treatment of complex patients.

DOS SANTOS, P. A.; TRIVELATO, A. E.; OLATE, S.; ASPRINO, L.; DE MORAES, M. Estabilidad como factor clave en la reparación de la nounión de osteotomía mandibular. Int. J. Morphol., 38(2):309-315, 2020

RESUMEN: La estabilidad de las osteotomías y de las fracturas son fundamentales para asegurar la adecuada reparación ósea; el objetivo de esta investigación fue analizar la reparación presente en sitios de pseudoartrosis realizando la limpieza de la zona previo a la fijación o manteniendo el tejido de la nounión en el mismo lugar durante la osteosíntesis. Se diseñó un estudio experimental incluyendo 18 conejos de raza Neozelandesa. Se formaron 6 grupos de estudios a quienes se relizó una osteotomía en el cuerpo mandibular y posterior instalación de músculo en el lugar de la osteotomía para fabricar un modelo de pseudoartrosis. En cirugía posterior se fijó con placa y tornillos. Se realizaron eutanasias a los 42 y 63 días para comparar los resultados de forma descriptiva mediante estudio histológico. No fue perdido ningún animal durante el experimento. En todas las muestras evaluadas se observó formación ósea en diferentes niveles de avance; defectos tratados con o sin el retiro del tejido involucrado en la pseudoartrosis presentaron una condición de reparación ósea comparables, determinando que la estabilidad de los segmentos óseos permite la reparación del tejido adyacente. El tejido cartilaginoso se presentó en algunas muestras asociadas a sectores con mayor presencia de formación ósea. La estabilización de la fractura es clave en la reparación ósea; la reparación se produce manteniendo o retirando el tejido presente en la pseudoartrosis.

PALABRAS CLAVE: No unión; Reparación ósea; Fractura mandibular; Osteotomía mandibular.

\section{REFERENCES}

Alister, J. P.; Veuthey, C.; Uribe, F.; Vásquez, B.; del Sol, M. \& Olate, S. Experimental model for the study of mandibular reconstruction. Options in rabbits Oryctolagus cuniculus. Int. J. Morphol., 35(3):1185-90, 2017.

Alkan, A.; Kilic, E.; Ocak, H.; Ozturk, M. \& Gunhan, O. Is it possible to shorten the jaws using contraction osteogenesis? J. Oral Maxillofac. Surg., 69(6):e195-200, 2011.

Boyan, B. D.; Schwartz, Z.; Swain, L. D.; Khare, A. G.; Heckman, J. D.; Ramirez, V.; Peters, P. \& Carnes Jr., D. L. Initial effects of partially purified bone morphogenetic protein on the expression of glycosaminoglycan, collagen, and alkaline phosphatase in nonunion cell cultures. Clin. Orthop. Relat. Res., (278):286-304, 1992.

Chen, C. C.; Zenaga, J.; Patel, R. \& Branham, G. Complications and reoperations in mandibular angle fractures. JAMA Facial Plast. Surg., 20(3):238-43, 2018

de Medeiros, R. C.; Sigua, E. A.; Navarro, P.; Olate, S. \& Albergaria Barbosa, J. R. In vitro mechanical analysis of different techniques of internal fixation of combined mandibular angle and body fractures. J. Oral Maxillofac. Surg., 74(4):778-85, 2016.

Delgado-Martínez, A. \& Alcántara-Martos, T. Agentes sistémicos que modifican la consolidación de las fracturas. Rev. Esp. Cir. Ortop. Traumatol., 50(Supl. 1):5-12, 2006.

Dodson, T. B.; Perrott, D. H.; Kaban, L. B. \& Gordon, N. C. Fixation of mandibular fractures: a comparative analysis of rigid internal fixation and standard fixation techniques. J. Oral Maxillofac. Surg., 48(4):362$6,1990$.

Donneys, A.; Nelson, N. S.; Page, E. E.; Deshpande, S. S.; Felice, P. A.; Tchanque-Fossuo, C. N.; Spiegel, J. P. \& Buchman, S. R. Targeting angiogenesis as a therapeutic means to reinforce osteocyte survival and prevent nonunions in the aftermath of radiotherapy. Head Neck, 37(9):1261-7, 2015

Gassner, R.; Tuli, T.; Hächl, O.; Rudisch, A. \& Ulmer, H. Craniomaxillofacial trauma: A 10 year review of 9,543 cases with 21,067 injuries. J. Craniomaxillofac. Surg., 31(1):51-61, 2003.

Gerstenfeld, L. C.; Alkhiary, Y. M.; Krall, E. A.; Nicholls, F. H.; Stapleton, S. N.; Fitch, J. L.; Bauer, M.; Kayal, R.; Graves, D. T.; Jepsen, K. J.; et $a l$. Three-dimensional reconstruction of fracture callus morphogenesis. J. Histochem. Cytochem., 54(11):1215-28, 2006.

Green, E.; Lubahn, J. D. \& Evans, J. Risk factors, treatment, and outcomes associated with nonunion of the midshaft humerus fracture. J. Surg. Orthop. Adv., 14(2):64-72, 2005.

Haug, R. H. \& Schwimmer, A. Fibrous union of the mandible: a review of 27 patients. J. Oral Maxillofac. Surg., 52(8):832-9, 1994.

Hsieh, T. Y.; Funamura, J. L.; Dedhia, R.; Durbin-Johnson, B.; Dunbar, C. \& Tollefson, T. T. Risk factors associated with complications after treatment of mandible fractures. JAMA Facial Plast. Surg., 21(3):21320, 2019.

Imai, Y.; Hasegawa, T.; Takeda, D.; Akashi, M.; Lee, S. Y.; Niikura, T.; Shibuya, Y.; Kurosaka, M. \& Komori, T. The osteogenic activity of human mandibular fracture haematoma-derived cells is stimulated by low-intensity pulsed ultrasound in vitro. Int. J. Oral Maxillofac. Surg., 43(3):367-72, 2014

Iwakura, T.; Miwa, M.; Sakai, Y.; Niikura, T.; Lee, S. Y.; Oe, K.; Hasegawa, T.; Kuroda, R.; Fujioka, H.; Doita, M.; et al. Human hypertrophic nonunion tissue contains mesenchymal progenitor cells with multilineage capacity in vitro. J. Orthop. Res., 27(2):208-15, 2009.

Jahagirdar, R. \& Scammell, B. E. Principles of fracture healing and disorders of bone union. Surgery (Oxford), 27(2):63-9, 2009.

Lamphier, J.; Ziccardi, V.; Ruvo, A. \& Janel, M. Complications of mandibular fractures in an urban teaching center. J. Oral Maxillofac. Surg., 61(7):745-9, 2003.

Lee, K. C.; Chuang, S. K. \& Koch, A. The healthcare cost of mandibular nonunions. J. Craniofac. Surg., 30(8):2539-41, 2019. 
Macki, M.; Syeda, S.; Kerezoudis, P.; Bydon, A.; Witham, T. F.; Sciubba, D. M.; Wolinsky, J. P.; Bydon, M. \& Gokaslan, Z. rhBMP-2 protects against reoperation for pseudoarthrosis and/or instrumentation failure: a matched case-control study of 448 patients. J. Clin. Neurosci., 32:99103, 2016.

Madsen, M. J.; Haug, R. H.; Christensen, B. S. \& Aldridge, E. Management of atrophic mandible fractures. Oral Maxillofac. Surg. Clin. North Am., 21(2):175-83, 2009.

Marsell, R. \& Einhorn, T. A. The biology of fracture healing. Injury, 42(6):551-5, 2011.

Meram, A. T.; Olate, S. \& Palmieri Jr., C. F. Is the three-dimensional strut plate an adequate fixation technique for mandibular symphysis fractures? J. Oral Maxillofac. Surg., 76(1):140-5, 2018.

Olate, S.; de Assis, A. F.; Pozzer, L.; Cavalieri-Pereira, L.; Asprino, L. \& de Moraes, M. Pattern and treatment of mandible body fracture. Int. J. Burns Trauma, 3(3):164-8, 2013.

Olate, S.; Vásquez, B.; Sandoval, C.; Vasconcellos, A.; Alister, J. P. \& del Sol, M. Histological analysis of bone repair in mandibular body osteotomy using internal fixation system in three different gaps without bone graft in an animal model. BioMed Res. Int., 2019:8043510, 2019.

Panteli, M.; Pountos, I.; Jones, E. \& Giannoudis, P. V. Biological and molecular profile of fracture non-union tissue: current insights. J. Cell. Mol. Med., 19(4):685-713, 2015.

Ricketts, S.; Gill, H. S.; Fialkov, J. A.; Matic, D. B. \& Antonyshym, O. M. Facial fractures. Plast. Reconstr. Surg., 137(2):424e-444e, 2016.

Rodriguez-Chessa, J.; Olate, S.; Netto, H. D.; Noia, C.; de Moraes, M. \& Mazzonetto, R. In vitro resistance of titanium and resorbable (poly Lco-DL lactic acid) oteosynthesis in mandibular body fracture. Int. J. Oral Maxillofac. Surg., 43(3):362-6, 2014.

Seemann, R.; Schicho, K.; Wutzl, A.; Koinig, G.; Poeschl, W. P.; Krennmair, G.; Ewers, R. \& Klug, C. Complication rates in the operative treatment of mandibular angle fractures: a 10-year retrospective. J. Oral Maxillofac. Surg., 68(3):647-50, 2010.

Spanjer, E. C. K.; Bittermann, G. K. P.; van Hooijdonk, I. E. M.; Rosenberg, A. J. W. P. \& Gawlitta, D. Taking the endochondral route to craniomaxillofacial bone regeneration: a logical approach? $J$. Craniomaxillofac. Surg., 45(7):1099-106, 2017.

Thomsen, P. \& Ericson, L. E. Titanium implants in rabbit knee joints. Acta Orthop. Scand., 58(3):265-9, 1987.

Tucker, D. I.; Zachar, M. R.; Chan, R. K. \& Hale, R. G. Characterization and management of mandibular fractures: lessons learned from Iraq and Afghanistan. Atlas Oral Maxillofac. Surg. Clin. North Am., 21(1):61-8, 2013

Wraighte, P. J. \& Scammell, B. E. Principles of fracture healing. The foundation years. Acute Care, 3(6):243-51, 2007.

Wu, C. C. \& Chen, W. J. Treatment of femoral shaft aseptic nonunions: comparison between closed and open bone-grafting techniques. J. Trau$m a, 43(1): 112-6,1997$.

\author{
Corresponding author: \\ Dr. Sergio Olate \\ Facultad de Odontología \\ Universidad de La Frontera \\ Claro Solar 115, Oficina 414 \\ Temuco \\ CHILE
}

Email: sergio.olate@ufrontera.cl

Received: 10-09-2019

Accepted: 10-12-2019 